\title{
Turkey Production in Gwagwalada Area Council of Federal Capital Territory, Abuja, Nigeria
}

\author{
Agbonika D.A, Folorunsho S.T
}

\begin{abstract}
Turkey production in gwagwalada is still on a small scale compared to other poultry birds' production. This paper estimated the cost and returns of turkey production using structured questionnaire to elicit information from 60 turkey producers in gwagwalada area council of federal capital territory, Abuja, Nigeria. Descriptive statistics was used to get socio-economic characteristics such as age, marital status, gender, level of education, etc of the turkey producers, net farm income model was used for cost and return analysis, gross margin model shows the profitability index. Findings of the study show that turkey production was carried out mainly as secondary activities by adults of 35-44 years of age. The respondents had formal education. Turkey production in the study area was found to be profitable with a profit investment ratio of 0.82 . The cost of feeding was as high as $50.8 \%$, fixed and variable input was $9.2 \%$ and $90.85 \%$ of the total cost of production respectively. The system of production was $85 \%$ semi-intensive style. The major diseases of turkeys reported in the area were fowl pox and ectoparasites. High cost of poults, high cost of feeds, unorganized market, poor extension services, high cost of vaccine/drugs, turkey theft were the constraints of turkey production in the area. Advantages of turkey production, proper management of turkey production and government roles in making turkey production lucrative were stated.
\end{abstract}

Index Terms - cost and returns analysis, turkey, turkey production

\section{INTRODUCTION}

The poultry population in Nigeria is estimated at 104.3 million comprising of 72.4 million chickens, 11.8 million of ducks, 4.7 million of guinea fowls, 15.2 million of pigeons and 0.2 million of turkey [1],[16]. According to [2],[7] in 2018 poultry production in Nigeria amounts up to 454 billion tonnes of meat and 3.8 million eggs per year, with a standing population of 180 million birds. About 80 million chickens are raised in extensive systems, 60 million in semi-intensive systems and the remaining 40 million in intensive systems [3]. The poultry is said to constitute a major animal protein source in this country. Turkey (Meleagris gallopavo) belongs to the family of birds called Meleagrididae. The young birds are called poults, the male birds are referred to as turkey cocks or toms while the female are called turkey hens [4]. Turkey production is an aspect of the poultry industry which although not popular in Nigeria, is very popular in many parts of the world especially Europe and America where they play

Agbonika D.A, Department of Agricultural Economics, Faculty of Agriculture, University of Abuja. PMB 117, Abuja, Nigeria

Folorunsho S.T, Department of Agricultural Economics and Extension, University of Jos, Nigeria. an important role in the supply of meat and eggs. The meat is especially considered by many as a luxury meat. Apart from their role in protein supply, they have an aesthetic value due to their beauty [4]. Turkeys are known to be adaptable to wide range of climatic conditions and can be raised successfully almost anywhere in the world if they are well fed and protected against diseases, predators and adverse weather conditions. Turkey is a poultry bird or domestic fowl that is easy to rear. In Nigeria, most people prefer to eat turkey meat compare to other meat like goat meat, cow meat, etc. apart from being the most demanded meat turkey is one of the fastest growing poultry fowl that can be reared. Poultry production forms an important component of Nigeria's livestock subsector. Poultry production is gaining popularity in the developing countries due to its role in bridging the protein malnutrition in their diets, economic empowerment of the resource poor segment of the society [5] [13]. Poultry production is practice in all levels ranging from subsistence to large scale commercial operations. Poultry meat and eggs are the most consumed animal protein; unrestricted by any religion or culture in Nigeria. It was recorded that the poultry industry contributed about $25 \%$ of the country's Agricultural GDP [6],[1]. Nigeria presently produces above $550,000 \mathrm{mt}$ of poultry meat per annum and 700,000mt of eggs according to [7],[8]. Despite this, Nigeria is far from meeting her domestic demand when compared with developed countries that involved in poultry production. As a provider of employment and income, poultry production constitutes an important form of livelihood for rural and urban dwellers. The bulk of the poultry meat and eggs are produced by small holders who adopt different production strategies in consonance with the little resources available to them while the commercial poultry production for meat and eggs are by urban and peri-urban dwellers [8]. Poultry offers the greatest scope for increasing the quantity and quality of animal protein. Poultry meat and eggs account for about $30 \%$ of total livestock output in Nigeria, of which eggs account for over 80 per cent. Turkey production in Nigeria is largely at the small holder level [9],[10]. The consistent rise in the cost of production of cow, goats and other meat that are common necessitate the need to explore other meat like Turkey [11]. According to [4], turkeys are more delicate than chickens and they are raised mainly for meat. Research on this poult that supply protein is very necessary in the Federal capital of Nigeria were population keep rising as a result of influcs of people from other state of the nation, urban-rural migration, birth increase etc. Turkey production has tremendous potential of covering the supply-demand gap of meat. It is on this note that this study attempt to describe the socio-economic characteristics 
of turkey farmers in gwagwalada area council, determine the various system of production used, determine the resource use efficiency in turkey production, determine the cost and returns and identify the constraints to turkey production in gwagwalada area council.

\section{STUDY AREA}

Gwagwalada Areal Council has an area of 1,043 km² and a population of 157,770 at the 2006 census [2]. Gwagwalada area council lies between latitude $07^{\circ} .57^{\prime} \mathrm{N}$ and longitude $07^{0} .7^{\prime} \mathrm{E}$. The area council consist of several people of different ethnic group due to the nature of jobs within the Federal Capital Territory Abuja and has several markets. The area council house universities, polytechnic, college of education, several ministry headquarters. This makes the area council a centre for high class elite that have interest for exotic meat. Turkey most times is given as gift during festive periods. Structured questionnaire was administered on the turkey farmers using face to face interview and oral discussion to get data. The primary data collected focused on variables such as educational status, marital status, sex, age, educational level, major occupation, household size and years of experience of turkey farmers. Others include; membership of cooperative societies, flock size, capital acquisition, management system and information concerning price of day-old poults, feed cost, feed source, quantity of feed, medication cost, building and other production equipment costs, labour cost and man-hours input for the production cycle and problems militating against turkey production in the study area. The data collected cover about 40 weeks.

\section{ANALYTICAL TECHNIQUES}

The following tools were used to analyse the data collected: Descriptive statistics was used to analyse the socioeconomic characteristics, system of production used by the turkey farmers and to identify the major problem militating against turkey production. This involves the use of range, percentages, and mean. Resource use Efficiency was calculated using efficiency ratio, Net Farm Income Analysis was used to determine the cost and returns of turkey production.

The equation for Efficiency ratio is expressed as;

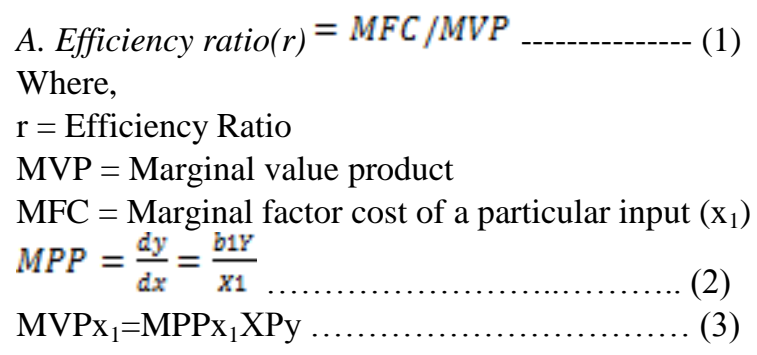

$Y$ and $X$ are the mean values of the output and input being considered respectively.

$\mathrm{bi}=$ is the estimated regression coefficient of input $\mathrm{xi}$

$\mathrm{Py}=$ is the unit price of output

$\mathrm{Xi}=$ is the various input i.e 1 to $\mathrm{n}$

If $r=1$, it means that resources are efficiently utilized. i. e

\section{$\mathrm{MVP}=\mathrm{MFC}=1$}

If $r>1$, it implies that resources are under-utilized and If $r$ $<1$, it implies that resources are over utilized.

The implicit equation is:

$\mathrm{Y}=\mathrm{F}(\mathrm{x} 1, \mathrm{x} 2, \mathrm{x} 3, \mu)$

Where,

$\mathrm{Y}=$ Turkeys output in $\mathrm{kg}$

$\mathrm{x}_{1}=$ Labour (man hours)

$\mathrm{x}_{2}=$ Feed $(\mathrm{kg})$

$\mathrm{x}_{3}=$ Capital

$\mu=$ errors term included to capture the effect of other variables not included in the Model.

Cobb -Douglas functional form of equation is considered fit in this research given that it allows for ease in estimating elasticity of production, return to scale and marginal productivity directly and the $\mathrm{R}^{2}$ value.it is expressed as;

$\log Y=\log a+b_{1} \log x_{1}+b_{2} \log x_{2}+b_{3} \log x_{3}+e$ (5)

B. Net Farm Income (NFI) as:

$N F I=T R-T C$

NFI = Net Farm Income

$\mathrm{TR}=$ Total Returns/ Receipts of turkey output ( $\mathrm{N})$

$\mathrm{TC}=$ Total cost $(\mathrm{TCV}+\mathrm{TFC})(\mathrm{N})$

$\mathrm{TVC}=$ Total variable cost $(\mathrm{N})$

$\mathrm{TFC}=$ Total fixed cost $(\mathrm{N})$

C. Gross Margin $(G M)=\mathrm{TR}-\mathrm{TVC}$

\section{RESULT AND DISCUSSION}

\section{A. Socio-economics Characteristics}

The result of the socio-economic characteristics of turkey farmers is as shown in table 1. The highest proportion of the turkey farmers' falls within the age group of 35-44 years. This implies that the majority of the turkey producers in the study area were in the productive and active age and they are likely to accept and adopt beneficial innovations and technologies faster. More married people $65 \%$ were involved in the turkey production than the single, this maybe as a result of sourcing for more funds to cater for the family. This in line with [12] that the bulk of turkey producers were married who took turkey production as means of supplementing family income. There were more female $(85 \%)$ turkey producers in the study area than the male counterpart of $(15 \%)$. This agrees with $[12],[4]$ that opined that poultry keeping is the activities of women but contradicts [10] that found out more male involvement in turkey production in Zaria. Majority of the turkey farmers in the study area had secondary education (45\%) showing they are enlighten to the extent of taking proper measures in the management of turkey. The respondents were majorly civil servant $(60 \%)$ and had 1-5 years of experience in the production of turkey. The household size $6-10$ person was $80 \%$ being the highest. This shows that the availability of labour was not difficult in handling the production of turkey enabling them have 1-20 
population of stock (70\%). The size of stock might be due to the fact that the cost of poult is high and most women involved in the production of turkey being civil servants do not have

Table 1: Socio-economic characteristics of Turkey farmers

\begin{tabular}{|c|c|c|}
\hline characteristics & frequency & percentage \\
\hline \multicolumn{3}{|l|}{ Age } \\
\hline $25-34$ & 12 & 20 \\
\hline $35-44$ & 24 & 40 \\
\hline $45-54$ & 18 & 30 \\
\hline $55-64$ & 6 & 10 \\
\hline$>65$ & 0 & 0 \\
\hline \multicolumn{3}{|l|}{ Marital status } \\
\hline single & 18 & 30 \\
\hline married & 39 & 65 \\
\hline divorced & 3 & 5 \\
\hline \multicolumn{3}{|l|}{$\operatorname{sex}$} \\
\hline male & 9 & 15 \\
\hline female & 51 & 85 \\
\hline \multicolumn{3}{|l|}{ Education level } \\
\hline No Education & 3 & 5 \\
\hline primary education & 12 & 20 \\
\hline secondary education & 27 & 45 \\
\hline higher institution & 18 & 30 \\
\hline \multicolumn{3}{|l|}{ Household size } \\
\hline $.1-5$ & 9 & 15 \\
\hline $.6-10$ & 48 & 80 \\
\hline $.11-15$ & 3 & 5 \\
\hline \multicolumn{3}{|l|}{ years of experience } \\
\hline $.1-5$ & 48 & 80 \\
\hline $.6-10$ & 6 & 10 \\
\hline $.11-15$ & 6 & 10 \\
\hline \multicolumn{3}{|l|}{ major occupation } \\
\hline Turkey farming & 21 & 35 \\
\hline civil sevant & 36 & 60 \\
\hline self employed & 3 & 5 \\
\hline \multicolumn{3}{|l|}{ population of stock } \\
\hline $.1-20$ & 42 & 70 \\
\hline $.21-40$ & 15 & 25 \\
\hline $.41-60$ & 3 & 5 \\
\hline$>60$ & 0 & \\
\hline \multicolumn{3}{|l|}{ Access to credit } \\
\hline personal savings & 42 & 70 \\
\hline friends/relatives & 12 & 20 \\
\hline bank & 6 & 10 \\
\hline
\end{tabular}

Source: Field survey 2018

easy access to credit as $70 \%$ make use of personal savings and only about $20 \%$ had access to bank loan.

\section{B. System of turkey production}

In the study area $75 \%$ of local bred and $25 \%$ of cross-bred were raised and two system of turkey production was identified. The turkey farmers used intensive and semi-intensive (which is the combination of deep litter and free range) system. The intensive system which is total confinement of the turkey was $25 \%$ while semi-intensive $(75 \%)$ was the major type of production system practiced. The farmer that practice semi-intensive did so to minimize cost of production in terms of feed purchase but those that practiced intensive system had the advantages of better control and protection of their turkeys against loss that can be due to thieves and other predators. The necessary health care practices such as sanitation, routine vaccination, avoidance of over-crowding and curative measures were carried out by the turkey farmers in the study area. Cleaning and disinfecting their turkey houses a week before the arrival of their poults were the sanitary measures carried out. They also carried out a routine and daily cleaning by removing turkey droppings and change of wet litter materials. Vaccination for turkeys was carried out Table 2 shows the type of vaccination done. Family labour $(85 \%)$ was the major source of labour while hire labour was $15 \%$. The feed used was $65 \%$ farmer's formulation to reduce cost of feed purchase and $35 \%$ commercial feed.

Table 2: Turkey Vaccination Schedule

\begin{tabular}{|l|l|l|l|}
\hline Disease & Vaccine & Route & $\begin{array}{l}\text { Age of } \\
\text { Turkey }\end{array}$ \\
\hline $\begin{array}{l}\text { Newcaslte } \\
\text { disease }\end{array}$ & $\begin{array}{l}\text { vaccine } \\
\text { Lasota }\end{array}$ & $\begin{array}{l}\text { Intraocular/drinking } \\
\text { water }\end{array}$ & 1st week \\
\hline Erysipelas & $\begin{array}{l}\text { Erysipelas } \\
\text { bactrin }\end{array}$ & $\begin{array}{l}\text { Intraocular/drinking } \\
\text { water }\end{array}$ & 8 weeks \\
\hline $\begin{array}{l}\text { Fowl } \\
\text { typhoid }\end{array}$ & $\begin{array}{l}\text { typhoid } \\
\text { vaccine }\end{array}$ & In drinking water & 8 weeks \\
\hline Coccidiosis & $\begin{array}{l}\text { xulfaquaino } \\
\text { xaline }\end{array}$ & In feed or water & 8 weeks \\
\hline $\begin{array}{l}\text { Fowl pox } \\
\text { Fowl pox }\end{array}$ & $\begin{array}{l}\text { vintra-muscular or } \\
\text { via living web }\end{array}$ & 12 weeks \\
\hline
\end{tabular}


Turkey Production in Gwagwalada Area Council of Federal Capital Territory, Abuja, Nigeria

\begin{tabular}{|c|c|c|}
\hline Activities & Frequency & Percentage \\
\hline \multicolumn{3}{|l|}{ Breed } \\
\hline Local & 45 & 75 \\
\hline Cross bred & 15 & 25 \\
\hline \multicolumn{3}{|l|}{ System of keeping } \\
\hline Intensive & 15 & 25 \\
\hline Semi-intensive & 45 & 75 \\
\hline \multicolumn{3}{|l|}{ Housing type } \\
\hline Cement & 54 & 90 \\
\hline Mud & 6 & 10 \\
\hline \multicolumn{3}{|l|}{ Labour } \\
\hline Family & 51 & 85 \\
\hline Hired & 9 & 15 \\
\hline \multicolumn{3}{|l|}{ Feed } \\
\hline Commercial & 21 & 35 \\
\hline Farmers formulatio & 39 & 65 \\
\hline Source: survey 2018 & & \\
\hline
\end{tabular}

Table 4: Marginal value productivities and Resourse use Efficie

\begin{tabular}{|l|c|c|c|c|c|c|}
\hline Variables & X & MPP & Bi & MFC & MVP & R \\
\hline Labour(manhr) & 655 & 0.81 & 0.64 & 500 & 37654 & 75.31 \\
\hline Capital(naira) & 56785 & 0.01 & 0.66 & 4000 & 300 & 0.075 \\
\hline Feed(kg) & 904 & 0.19 & 0.36 & 2500 & 1500 & 0.6 \\
\hline
\end{tabular}

source: survey 2018

$$
\begin{aligned}
& \mathrm{Y}=670 \\
& \mathrm{MPP}=\mathrm{BiY} / \mathrm{X} \\
& \mathrm{Y}=\text { output mean } \\
& \mathrm{X}=\text { input mean } \\
& \mathrm{Bi}=\text { regression coefficient }
\end{aligned}
$$

The farmers kept the turkeys for a longer period (40 weeks) before disposing them thereby feeding the turkeys beyond the economic weight gain. Also over utilization of feed could be due to wastage of feed by the turkey producers as a result of over filling of feeders and the use of spoilt feeders. The feeds therefore need to be used efficiently by using good feeders and by disposing matured turkeys as soon as they attain their economic weights.

Other measures to prevent diseases and death of turkey like: Desnooding, Beak Trimming (Debeaking), Claw Clipping, wing clipping were also done. Desnooding is the removal of the snood to prevent injuries from pecking or fighting which may result to erysipelas disease. The snood can be cut off close to the head with sharp, pointed scissors around 3 week old or can be remove by fingernails at day old. Debeaking is done in order to control feather pecking and cannibalism especially when they are to be raised in intensive housing system [13]. It is usually done at 10 days of age. Beak of adult turkeys can also be trimmed using nail clippers or appropriate scissors. Claw Clipping is the removal of toenails which is usually done at the hatchery but it can also be done at 5 weeks old [14]. This is to prevent tearing of flesh during fight and mating. The most common form of toe clipping involves cutting the inside and middle toe on each foot. Toes can be cut with surgical scissors, a nail clipper or a modified hot-blade debeaker. The semi- intensive system practice in the area of study which is a combination of confinement and range practice wing clipping at 15 week old in order to prevent flight over the range fence. This practice prevents the turkeys from jumping out of the range into predators.

\section{Resource use Efficiency}

: The economic efficiency of resources used based on the ratios of marginal value product (MVP) to marginal factor cost (MFC) in table 4 indicated that feed and capital were over utilized $(r=0.60$ and $r=0.075)$ respectively while labour was underutilized $(\mathrm{R}=$ 75.308).

\section{Cost and Returns analysis}

Table 5 shows the cost and returns to an average turkey farmer in Gwagwalada area council. The total revenue was $\$ 739,600.00$, the variable cost was $90.85 \%$ ( 123000 ) of total cost and fixed cost was 9.2\% ( 12500 ). The cost of feeds was 50.8\% ( the highest amount confirming that feed constitute a major ingredient in turkey production. Labour was $19.2 \%$ ( 26000) followed by drugs/veterinary service which was 11.8\% ( 16000 ). Housing and equipment made up the fixed costs which was just $9.2 \%$ compared to $90.85 \%$ variable costs. The variable cost seems to be the largest value in the production of turkey in the study area and this is in line with [10],[15] that variable costs most times surpasses fixed costs in turkey production. The sale of matured turkey at the end of the production cycle amounted to $\$ 654000$, also the farmers sold their poult, manure from the production and feed empty bags were sold to generate income giving the farmer the total revenue of $\$ 739600$. 


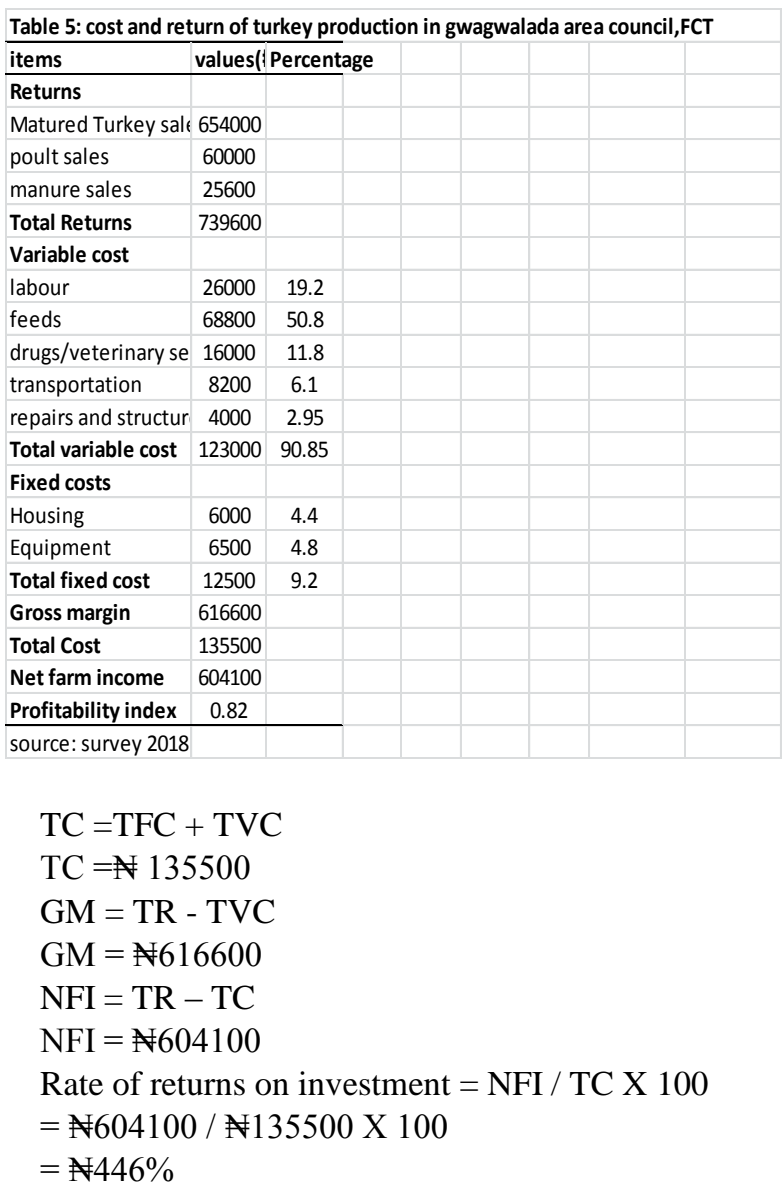

The rate of return on investment for turkey production in the study area was $\$ 446 \%$, the net farm income of 604100 and capital turnover of 5.45 implying that for every naira invested there is a return of $\$ 5.45$ to turkey farmer. The profit investment ratio which is an index that represents the relationship between the cost and benefit of turkey production is less than one (0.82) this depicts the need for turkey production commercialization and necessity of extension agent reaching out to turkey farmers for capacity building. There is great potential for turkey production in the study area if turkey farming is improved.

\section{PROBLEMS OF TURKEY PRODUCTION}

Table 6 shows the problems militating against turkey production. The major problems identified to be militating turkey production in the study area are high cost of poult. A poult cost about 2100 which is quite expensive compared to other poultry birds. The cost of feed was Identified as the second major problem followed by lack of organized market $(18.33 \%)$, poor extension service $(13.33 \%)$. Inadequate capital $(10 \%)$, poor veterinary services (5\%), and theft of turkey $(3.33 \%)$.
Table 6 : Major problems identified militating against turkey production in the study area

\begin{tabular}{|l|c|c|}
\hline Problems & Frequency & $\%$ \\
\hline High cost of poult & 18 & 30 \\
\hline High cost of feed & 12 & 20 \\
\hline Lack of organized market & 11 & 18.33 \\
\hline Poor extension services & 8 & 13.33 \\
\hline Inadequate capital & 6 & 10 \\
\hline Poor vertinary services & 3 & 5 \\
\hline Theft of turkey & 2 & 3.33 \\
\hline Total & 60 & 100 \\
\hline
\end{tabular}

\section{CONCLUSION}

Turkey production in the study area has the potential of increasing profit. There is need to encourage the farmers in terms of setting up an organized market for the sale of the turkeys. Extension agent/workers should mobilize the turkey farmer to increase production via workshops/seminars and educating the farmer on appropriate management system to adopt in the area. The inability of the farmers to easily access credit was one of the identified problems; therefore government should make access to credit more flexible for farmers. The production of turkey will create job opportunity for people and also help close the demand-supply deficit of protein. Private sectors should also invest in the production of turkey in terms of feed production to lower the high cost of feed production.

\section{REFERENCES}

[1] FAO. Small-Scale Poultry Production. FAO Corporate Document Repository. FAO Animal Production and Health Paper, (2002) No. 35, Rome.

[2] Federal Office of Statistics (FOS). Digest of Statistics. Demographic Report of Nigerian States presented by the Federal Office of Statistics, Lagos. (1994).

[3] Nwagu, B.I .'" Production and Management of Indigenous Poultry Species', In: Gefu, J.O; I.A. Adeyinka and A.A. Sekoni. (eds), Poultry Production in Nigeria, pp. 10-19. Training Workshop held at National Animal Production Research Institute (NAPRI), Shika, Zaria. . (2002), 1-6 September.

[4] Ogundipe, S.O. and Dafwang, I.I "Turkey Production in Nigeria", National Agricultural Extension Research and Liaison Service (NAERLS) Bulletin No. 22. . (1980). Pp 2-22.

[5] Tanko, L.." Efficiency of Resource Use: The Case of Poultry Production in Kebbi State', In: Ukachukwu, S.N; J.A. Ibeawuchi; S.N. Ibe; A.G. Ezekwe and S.F Abasiekong. (eds), Animal Production in the New Millennium: Challenges and Options, (2000) pp. 392-393. Book of Proceedings of 25th Annual Conference, Umudike, 19- 23 March.

[6] Food and Agricultural Organisation In: Dale Coyler (2002). Econometric Analysis of U.S. Turkey Exports. (1999). pp 1-2. West Virginia University, Morgantown. 
[7] ASL 2050..." Livestock production systems" spotlight Nigeria. FAO, Rome, Italy. 2018

[8] Eduvie, L.O 'Poultry Production as an important Component of Nigeria's Livestock Sub sector', In: Gefu, J.O; I.A Adeyinka and A.A. Sekoni (eds) Poultry Production in Nigeria, . (2002). pg. 6. Training Workshop held at the National Animal Production Research Institute (NAPRI), Shika, Zaria, 1-6 September.

[9] Udokainyang, A.O. Growth performance carcass characteristics and economic of local poults fed varying dietary energy levels. Project Reports, University of Agriculture, Umudike. (2001)

[10] Ajala M.K, Nwagu B.I, Sekoni A.A and A.O.K Adesehinwa: The Profitability of Turkey Production in Zaria, Kaduna State. Asian Journal of Information Technology (2007) 6 (1): 27-33.

[11] Peters, S.O; C.O.N. Ikeobi and O.O. Bankole. Smallholder Local Turkey Production in Ogun State, Nigeria. Paper Presentation at the College of Animal and Livestock Production, University of Agriculture, Abeokuta, Nigeria, (1994) pp.1-11.

[12] Olayemi, J.A. and F.A. Roberts Poultry Production in Warm Wet Climates. University Press, Ibadan (1982)., p.1-10

[13] Mbanasor, J.A. and Sampson, A. Socio-economic Determinants of Turkey Production among Nigerian Soldiers. International Journal of Poultry Science, Nigeria. .(2004) 3(8); 497-502.

[14] Abubakar, B.Y; O.O. Oni; I.A. Adeyinka; B.I. Nwagu; S.O. Ogundipe and A.A. Sekoni 'Poultry Layer Grand Parent Stock Development at National Animal Production Research Institute (NAPRI) Shika'”. In Gefu, J.O; I.A. Adeyinka and A.A. Sekoni. (eds), Poultry Production in Nigeria, (2002). pp. 52-53. Training Workshop held at the National Animal Production Research Institute (NAPRI), Shika, Zaria, Nigeria. 1-6 September.

[15] Dale Coyler Econometric Analysis of U.S. Turkey Exports. Paper presented at the Annual Meeting of the North eastern Agricultural and Resource Economics Association, New Green Wich, West Virginia University, Morgantown, (2000). pp. 1-6.

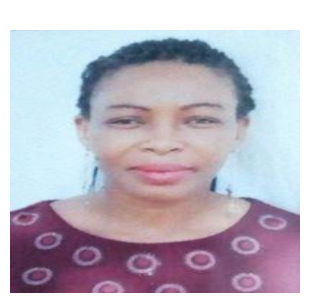

Agbonika D.A is an Agricultural Economics in University of Abuja where she also serves as a Data Analyst. She obtained B.Tech Agricultural Economics and Extension option from Abubakar Tafawa Balewa University Bauchi, Nigeria in 2005, MSc degree in the same field in 2015 from Ahmadu Bello University Zaria, Nigeria and $\mathrm{PhD}$ degree in Agricultural Economics (inview) University of Abuja. Presently researching on Rice value chain in the North-central of Nigeria, A member of JISNAS (Japan Intellectual Support Network in Agricultural Science), JAAN(JICA Alumni Association of Nigeria),Agricultural Society of Nigeria (ASN), Farm Management Association of Nigeria (FAMAN),National Association of Agricultural Economics (NAAE),etc. She has numerous local and internal Journal publications to her credit.

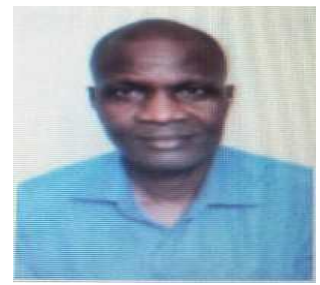

Dr. Solomon T. Folorunso obtained a Bachelor of Agriculture Degree (Agricultural Economics \& Farm Management option) from Federal University of Agriculture, Abeokuta, Nigeria in 1998, an M.Sc. Degree in 2011 and Ph.D Degree in 2015 both in Agricultural Economics from Ahmadu Bello University, Zaria, Nigeria. He is currently a lecturer in the Department of Agricultural Economics \& Extension, University of Jos, Jos-Nigeria. He has numerous local and internal Journal publications to his credit. 